\title{
CHANGES IN CONCENTRATION OF CREATINE KINASE, BODY COMPOSITION AND LIPOPROTEIN DURING MENSTRUAL CYCLE
}

\author{
Laura Daniusevičiūtè $\dot{1}^{1,2}$, Marius Brazaitis ${ }^{1}$, Albertas Skurvydas ${ }^{1}$, Saulè Sipavičienè ${ }^{1}$, \\ Vitas Linonis $^{2}$, Jurgita Piečaitiené ${ }^{1}$, Nerijus Eimantas ${ }^{1}$ \\ Lithuanian Academy of Physical Education ${ }^{1}$, Kaunas, \\ Kaunas University of Technology ${ }^{2}$, Kaunas, Lithuania
}

\begin{abstract}
Laura Daniusevičiūtė. PhD student in Biomedical Sciences, Lithuanian Academy of Physical Education, Assistant at the Centre for Physical Education and Sport, Kaunas University of Technology. Research interests - dependence of motor control fatique on women's menstrual cycle.
\end{abstract}

\begin{abstract}
The aim of our study was to establish the dependence of changes in the concentration of creatine kinase, body composition and lipoprotein on the follicular phase and ovulation. The subjects were healthy and physically active women $(n=9)$ with normal menstrual cycle, whose age was $19-23$ years, body weight $-58.2 \pm 6.1 \mathrm{~kg}$, height $-168.4 \pm$ $5.6 \mathrm{~cm}$. All the participants had not used oral contraceptives for 6 months and had regular menstrual cycles. Ethical approval was obtained from Kaunas Regional Biomedical Research Ethics Committee (Report Number BE-2-24). Each subject measured her basal body temperature every morning 3 months before the experiment. The basal body temperature increased approximately by $0.3{ }^{\circ} \mathrm{C}$ after ovulation, which is sustained throughout the luteal phase. By the basal body temperature we estimated the approximate day of ovulation, and thus the relative length of follicular and luteal phases. We performed two experiments with each participant: in the follicular phase and ovulation. The days of experiment were chosen considering the duration of the menstrual cycle and the ovulation day of each participant. At the beginning of every experiment the body composition values: weight, BMI, body fat mass (\%), body fat mass $(\mathrm{kg})$, muscle mass $(\mathrm{kg})$, water amount $(\mathrm{kg})$ were estimated. The samples of $5 \mathrm{ml}$ and $2 \mathrm{ml}$ venum blood were taken to establish the amount of estradio17 $\beta$-estradiol, serum total cholesterol, high density lipoprotein cholesterol, triglyceride and creatine kinase concentration. Creatine kinase concentration was measured 24, 48, 72 hours after the load (100 jumps on the vertical jump force plate from a $75 \mathrm{~cm}$ stage). After 10-15 min of not intensive warming-up (slow pedaling veloergometer, heart rate 120-130 b/ min) 100 jumps on the vertical jump force plate from a $75 \mathrm{~cm}$ stage were performed, with the knee joints flexed up to the angle of $90^{\circ}$ (hands on loin). Hormonal analysis confirmed that the subjects were in the correct estrogen status, but no significant change was observed in the body composition and triglyceride values over the menstrual cycle. High density lipoprotein cholesterol and serum total cholesterol values significantly differed in ovulation compared to the values in the follicular phase. Due to the small sample size CK concentration did not significantly differ during the menstrual cycle, but the amount of CK concentration was lager in the follicular phase than in ovulation.
\end{abstract}

Keywords: lipoprotein contentration, creatin kinase, body composition, follicular phase, ovulation.

\section{INTRODUCTION}

$\mathrm{M}$ ost women affirm that their body mass changes during their menstrual cycle. They report changes in bodyweight and a bloated feeling throughout the menstrual cycle, indicating potential changes in the distribution of body fluids. There are many factors that influence body mass changes aside from the quantity of water, fat and muscles. All these depend on hormones, which balance the metabolism process and water retention (Janse de Jonge, 2003). H. J. Chihal
(1990) attributes some premenstrual symptoms (PMS) to increased water retention. J. B. Barnett et al. (2002) followed a group of women composed of individuals who had evident PMS and those who had none, and their average total body water was significantly different. C. N. Gleichauf and D. A. Roe (1989) repeated the measurements with bioimpedance several times during the cycle, and found some influence of changes in water retention or body mass, impedance and fat mass. Most studies 
found no significant change in bodyweight over the menstrual cycle (Stachenfeld, 2008). There are also reports that estrogens act as pro-oxidants when administered in the form of pharmacological contraceptives (i.e., ethinyl estradiol/norethisterone) (Kose et al., 1993). Finally, a direct interaction between estrogens and membrane phospholipids may occur, thus affecting phospholipid alignment and stabilizing the membrane (Kagan et al., 1994). This would be in a very similar fashion to the actions of cholesterol and the anticancer drug tamoxifen (Tiidus, 1995). In response to oxidation stress have been considered to rely on the better antioxidant protection provided by estrogens acting as antioxidants capable of scavenging the reactive oxygen species (Sugioka et al., 1987), modulating activities of antioxidant enzymes and decreasing oxidative modification of low-density lipoproteins (Massafra et al., 2000). The intent of this study was to test the hypothesis that estrogen levels influence the development in water retention, body mass, concentration of lipoprotein and kreatine kinase during the menstrual cycle.

The aim of our study was to establish the dependence of changes in the concentration of creatine kinase, body composition and lipoprotein on the follicular phase and ovulation.

\section{RESEARCH METHODS}

Subjects - healthy and physically active women $(\mathrm{n}=9)$ with normal menstrual cycle, whose age was $19-23$ years, body weight $-58.2 \pm$ $6.1 \mathrm{~kg}$, height $-168.4 \pm 5.6 \mathrm{~cm}$. All the participants had not used oral contraceptives for 6 months and had regular menstrual cycles. Ethical approval was obtained from Kaunas Regional Biomedical Research Ethics Committee (Report Number BE-2-24).

Estimation of basal body temperature. Basal body temperature (BBT) estimation is a method for identifying the approximate day of ovulation, and thus the relative length of follicular and luteal phases (Horvath, et al., 1982; Bauman, 1981). Each subject measured her BBT every morning 3 months before the experiment. BBT have increased approximately by $0.3{ }^{\circ} \mathrm{C}$ after ovulation, which is sustained throughout the luteal phase (Figure 1).

Using BBT method we chose subjects for the study on their early-follicular phase, when estrogen and progesterone concentrations are low, and on ovulation, when estrogen concentrations are hight (Bauman, 1981).

Estimation of estrogen concentrations. At the beginning of every experiment the sample of $5 \mathrm{ml}$ venum blood was taken to establish the menstrual cycle phases: follicular phase and ovulation and also the amount of estradio $17 \beta$-estradiol. In our study we measured estradio17 $\beta$-estradiol concentration in blood on the second day of the menstrual cycle (follicular phase) and on the fourteenth day of the menstrual cycle (ovulation). Immunoassay method was used for the in vitro quantitative determination of estradio17 $\beta$-estradiol in human serum and plasma. The electrochemiluminescence immunoassay was intended for the use of Elecsys and cobas e immunoassay analyzers. The Elecsys Estradiol II assay employs a competitive test principle using a polyclonal antibody specifically directed against $17 \beta$-estradiol (USA). Endogenous estradiol released from the sample by mesterone competes with the added estradiol derivative labeled with ruthenium complex ${ }^{a}$ for the binding sites on the biotinylated antibody. The analyzer automatically calculates the analyte concentration of each sample in pmol / L, pg / L or ng / L.

Estimation of biochemical blood analysis. At the begining of every experiment the sample of 2 $\mathrm{ml}$ venum blood was taken to establish serum total cholesterol (Tchol), high density lipoprotein cholesterol (HDL-ch), triglyceride (TG) and creatine kinase $(\mathrm{CK})$ concentration. Immunoassay method
Figure 1. Basal body temperature measurements throughout the three phases of the menstrual cycle

Note. * - a significant difference compare with the beginning $(\mathrm{p}<0.05)$.

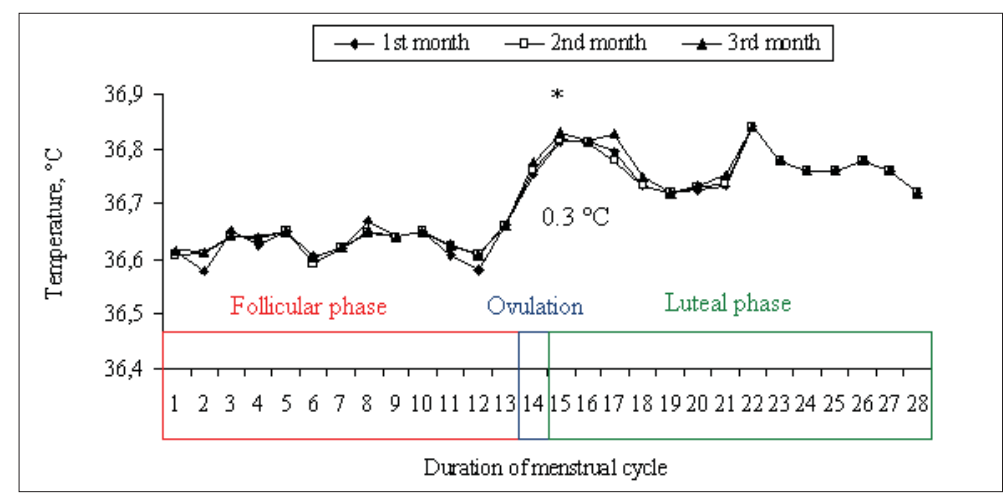


was used applying „SPOTCHEM TM EZ Sp 4430 ARKRAY" biochemical analyzer (Japan).

Estimation of body composition values. Weight, body mass index (BMI), body fat mass $(\%)$, body fat mass $(\mathrm{kg})$, muscle mass $(\mathrm{kg})$ and water amount $(\mathrm{kg})$ were estimated using body composition analyzer "TANITA BODY COMPOSITION ANALYZER TBF - 300A" (USA), where we inserted the values of the subject's height, age and physical capacity.

Testing schedule. With each participant we carried out 2 experiments: in the follicular phase and ovulation. The days of the experiments were chosen considering the duration of the menstrual cycle and the ovulation day of each participant. At the begining of every experiment the body composition values: weight, BMI, body fat mass $(\%)$, body fat mass $(\mathrm{kg})$, muscle mass $(\mathrm{kg})$, water amount $(\mathrm{kg})$ were estimated. The samples of $5 \mathrm{ml}$ and $2 \mathrm{ml}$ venum blood were taken to establish the amount of estradio17 $\beta$-estradiol, Tchol, HDL-ch, TG, CK concentration. CK concentration was measured 24, 48, 72 hours after the load (100 jumps on the vertical jump force plate from a $75 \mathrm{~cm}$ stage). After $10-15 \mathrm{~min}$ of not intensive warming-up (slow pedaling velorgometer, heart rate $120-130 \mathrm{~b} / \mathrm{min}) 100$ jumps on the vertical jump force plate from a $75 \mathrm{~cm}$ stage were performed and in the amortization phase the knee joints were flexed up to the angle of $90^{\circ}$ (hands on loin).
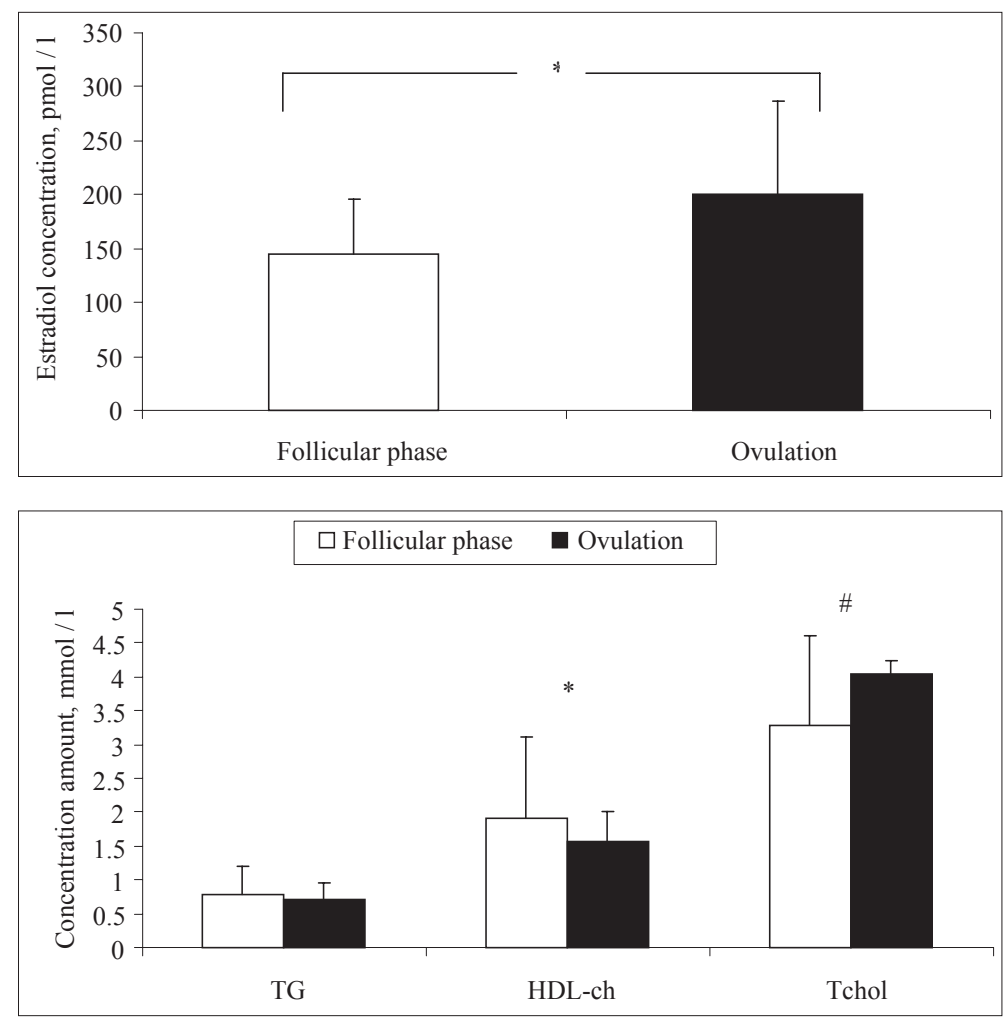

Statistical analysis. Values of the basal body temperature estrogen concentrations, biochemical blood analysis and body composition were averaged and used for the analyses. Standard deviation was calculated as well. For each dependent variable, a repeated measure ANOVA was run to determine the differences within the testing sessions. Additionally for each dependent variable, change scores between the follicular phase and ovulatory measures were calculated. The level of significance was set a priori at $\mathrm{p}<0.05$ for all analyses.

\section{RESULTS}

Hormonal analysis confirmed that the subjects were in the correct estrogen status and the levels were significantly greater in the ovulation group than the follicular phase group $(\mathrm{p}<0.01)$ (Figure 2).

BMI, body fat mass (\%), body fat mass ( $\mathrm{kg})$, muscle mass $(\mathrm{kg})$ values and water amount $(\mathrm{kg})$ did not significantly differ in ovulation compared to the values in the follicular phase (Table) $(\mathrm{p}>0.05)$.

The values of triglyceride (TG) did not significantly differ in ovulation compared to the values in the follicular phase ( $p>0.05)$, but we found significant difference in the values of high density lipoprotein cholesterol (HDL-ch) and serum total cholesterol (Tchol) in ovulation

Figure 2. Estradiol concentration in the ovulation and the follicular phase groups $(\mathbf{p}<0.01)$

Note. * - a significant difference comparing values with ovulation and follicular phase $(\mathrm{p}<0.01)$.

Figure 3. Concentration amount of serum total cholesterol (Tchol), high density lipoprotein cholesterol (HDL-ch), triglyceride (TG) in the ovulation and follicular phase groups $(\mathbf{p}<0.01)$

Note. * - significant difference in HDL-ch values comparing the ovulation and the follicular phases $(\mathrm{p}<0.01)$; \# - significant difference in Tchol values comparing the ovulation and the follicular phase $(\mathrm{p}<0.01)$. 
Table. Body composition values in the ovulation and the follicular phase
Figure 4. Concentration amount of creatine kinase $(\mathrm{CK})$ in the ovulation and follicular phase groups
Note. * - significant difference compared to the beginning $(\mathrm{p}<0.05)$.

\begin{tabular}{|c|c|c|c|}
\hline & Follicular phase & Ovulation & p-value \\
\hline BMI & $21.3 \pm 1.77$ & $21.3 \pm 1.70$ & $>0.05$ \\
\hline Body fat mass, \% & $23 \pm 5.96$ & $23.95 \pm 5.39$ & $>0.05$ \\
\hline Body fat mass, kg & $14.48 \pm 5.05$ & $14.38 \pm 4.58$ & $>0.05$ \\
\hline Muscle mass, $\mathrm{kg}$ & $47.07 \pm 2.59$ & $46.23 \pm 1.56$ & $>0.05$ \\
\hline Water amount, $\mathrm{kg}$ & $34.20 \pm 1.30$ & $33.85 \pm 1.15$ & $>0.05$ \\
\hline
\end{tabular}

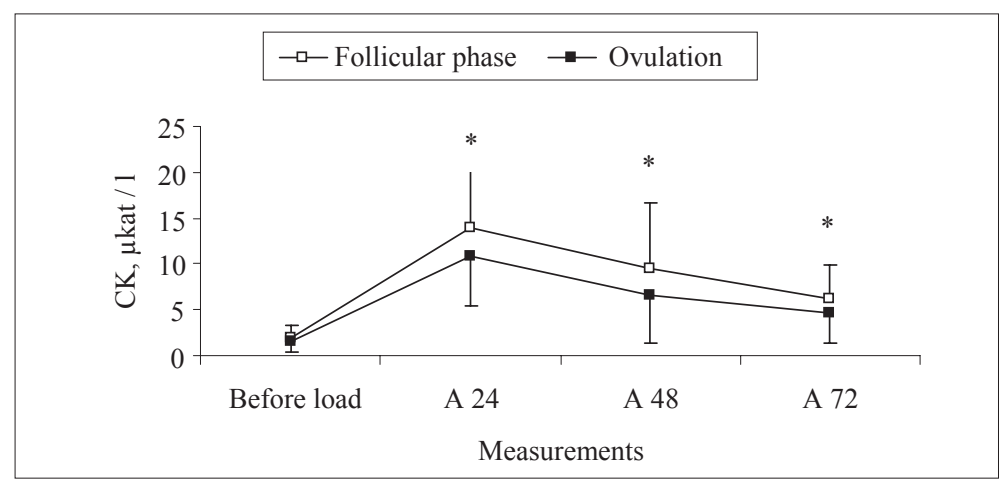

compared to the values in the follicular phase $(\mathrm{p}<0.01)$ (Figure 3).

The values of creatine kinase (CK) concentration did not significantly differ in ovulation compared to the ones in the follicular phase $(p>0.05)$, but the amount of CK concentration was lager in the follicular phase than in ovulation (Figure 4). The values of creatine kinase (CK) concentration differ significantly compared to the initial values in ovulation and the follicular phase separately $(\mathrm{p}<0.05)$ (Figure 4).

\section{DISCUSSION}

The purpose of our study was to establish the dependence of changes in the concentration of creatine kinase, body composition and lipoprotein on the follicular phase and ovulation. The present results showed, that estradiol concentration was higher in ovulation than in the follicular phase, when the ovulation day calculated was day 14 , and the follicular phase - day 2 in the female participants. Hoffman et al. (2008) collected saliva sample and maintained that in 28 female participants, whose age $22.4 \pm 3.4$ years the estrogen peak was observed on day 11 of their menstrual cycle. According to the classical terminology, when the menstrual cycle phase is 28 days, ovulation occurrs on day 14 , and the follicular phase - on the $1^{\text {st }}-13^{\text {th }}$ days (Janse de Jonge, 2003). The indication of corresponding hormone concentrations on ovulation day estradiol is high, and on the day of follicular phase estradiol is low (Janse de Jonge, 2003).

The dependence on BMI, body fat mass (\%), body fat mass $(\mathrm{kg})$, muscle mass $(\mathrm{kg})$ values and water amount $(\mathrm{kg})$ did not significantly differ in ovulation compared to the values of follicular phase. Most studies found no significant change in bodyweight over the menstrual cycle (Horvath et al., 1982; De Souza et al., 1990; Stachenfeld et al., 2000). These studies, however, conducted testing on only two or three occasions throughout the menstrual cycle. In a study with daily bodyweight measurements in 28 young women, the highest bodyweight was found in the late luteal phase and the first days of menstruation (Watson et al., 1965). The time of ovulation in this study was estimated from BBT patterns and was not verified with hormone measurements. Many women report changes in bodyweight and a bloated feeling throughout the menstrual cycle, indicating potential changes in the distribution of body fluids. In the study of sex hormone effects on body fluid regulation Stachenfeld (2008) maintained that estradiol lowered the operating point for osmoregulation of arginine vasopressin and thirst and increased plasma volume. Although the total body water and sodium content are only mildly affected, the data presented in the article suggest that reproductive hormones alter homeostatic set points for body 
fluid and tonicity. Also, for bodyweight loss during exercise, some studies have reported no changes over the menstrual cycle (Stachenfeld et al., 1999). These findings may indicate that estrogen and progesterone changes during the menstrual cycle do not affect fluid regulation. An alternative explanation may be that the menstrual cycle affects the distribution of fluid within the body, rather than absolute fluid retention or excretion. Ziomkiewicz et al. (2008) maintain that women with very low (below 22\%) and high body fat (above 31\%) had 25-35\% lower levels of estradiol than women with low or average body fat. Several authors have demonstrated that, increased adiposity and obesity are related to high androgenic activity in women (Wabitsch et al., 1995; Norman, Clark, 1998).

The present results showed, that values of triglyceride (TG) did not significantly differ in ovulation compared to the values in the follicular phase $(p>0.05)$, but we found significant differences in the values of high density lipoprotein cholesterol (HDL-ch) and serum total cholesterol (Tchol) in ovulation compared to the values in the follicular phase $(\mathrm{p}<0.01)$. Several studies reported changes in exercise substrate metabolism over the menstrual cycle suggesting an enhanced lipid metabolism during the mid-luteal phase (Hackney, 1999; Braun et al., 2000). Other investigations found no difference in total or high density lipoprotein (HDL-ch) cholesterol between the phases of the menstrual cycle (Moller et al., 1996). These results suggest that metabolism is likely to be affected by an interaction between menstrual cycle phase and nutritional status.

In the study of serum CK activity after isometric exercise in premenopausal and postmenopausal women Buckley-Bleiler et al. (1989) observed significant increases in CK, but no between-group differences in different menstrual cycle. The sample size of the postmenopausal group was small $(\mathrm{n}=6)$ allowing great variability to exist. This can also explain the results of our study when the values of CK concentration did not significantly differ in ovulation than in the follicular phase $(p>0.05)$, but the amount of $\mathrm{CK}$ concentration was lager in the follicular phase (where estradiol is low) compared to ovulation (where estradiol is high). The sample size of our study was also small $(n=9)$. Carter et al. (2001) tested the hypothesis that estrogen levels influence the development of muscle tissue damage following eccentric exercise in women $(n=27)$. The current results clearly demonstrate that the CK response following eccentric exercise of women with higher estrogen is less than that of women with lower estrogen levels. These findings suggest that elevated estrogen levels have a protective effect on muscle tissue following eccentric exercise. The mechanism of this protective effect is unclear but may be related to the antioxidant characteristics and membrane stability properties associated with estrogen and its derivatives. A direct interaction between estrogens and membrane phospholipids may occur, thus affecting phospholipids alignment and stabilizing the membrane (Kagan et al., 1994; Carter et al., 2001). This would be in a very similar fashion to the actions of cholesterol and the anticancer drug tamoxifen (Tiidus, 1995). Surprisingly, CK activity at rest did not significantly depend on estrogen concentrations, despite the evidence given by many authors who pointed to the antioxidant properties of estradiol and the important role of female sex-hormones in maintaining the integrity of the cell membrane post-exercise and limiting CK release from skeletal muscle (Tiidus 2000). The mechanism of this protective effect is unclear but may be related to the antioxidant characteristics and membrane stability properties associated with estrogen and its derivatives.

\section{CONCLUSIONS}

Hormonal analysis confirmed that subjects were in the correct estrogen status, but no significant change was observed in body composition and triglyceride values during the menstrual cycle. High density lipoprotein cholesterol and serum total cholesterol values significantly differ in ovulation compared to the values in the follicular phase.

Due to the small sample size CK concentration did not significantly differ during the menstrual cycle, but the amount of CK concentration was lager in the follicular phase than in ovulation. 


\section{LITERATURE}

Barnett, J. B., Woods, M. N., Rosner, B., McCormack, C., Floyd, L., Longcope, C., Gorbach, S. L. (2002). Waist-tohip ratio, body mass index and sex hormone levels associated with breast cancer risk in premenopausal Caucasian women. The American Journal of the Medical Science, 2 , $170-176$.

Bauman, J. E. (1981). Basal body temperature: unreliable method of ovulation detection. Fertility and Sterility, 36 (6), 729-733

Braun, B., Mawson, J. T., Muza, S. R. (2000). Women at altitude: Carbohydrate utilization during exercise at 4,300 m. Journal of Applied Physiology, 88 (1), 246256.

Buckley-Bleiler, R., Maughan, R. J., Clarkson, P. M., Bleiler, T. L., Whiting, P. H. (1989). Serum creatine kinase activity after isometric exercise in premenopausal and postmenopausal women. Experimental Aging Research, 15, 195-198.

Carter, A., Dobridge, J., Hackney, A. C. (2001). Influence of estrogen on markers of muscle tissue damage following eccentric exercise. Human Physiology, 27, 5, 626-630.

Chihal, H. J. (1990). Premenstrual syndrome: An update for the clinician. Obstetrics \& Gynecology Clinics of North America, 17 (2), 457-479.

Gleichauf, C. N., Roe, D. A. (1989). The menstrual cycle's effect on the reliability of bloimpedance measurements for assessing body composition. American Journal of Clinical Nutrition, 50, 903-907.

Hackney, A. C. (1999). Influence of oestrogen on muscle glycogen utilization during exercise. Acta Physiologica Scandinavica, 167 (3), 273-274.

Hoffman, M., Harter, R. A., Hayes, B. T., Wojtys, E. M., Murtaugh, P. (2008). The interrelationships among sex hormone concentrations, motorneuron excitability, and anterior tibial displacement in women and men. Journal of Athletic Training, 43 (4), 364-372.

Horvath, S. M., Drinkwater, B. L. (1982). Thermoregulation and the menstrual cycle. Aviaion Space and Environmental Medicine, 53 (8), 790-794.

Janse de Jonge, X. A. K. (2003). Effects of the Menstrual Cycle on Exercise Performance. Sports Medicine, 33 (11), $833-851$.

Kagan, V., Spirichev, V., Serbinova, E. et al. (1994). The significance of vitamin e and free radicals in physical exercise. In Nutrition in Exercise and Sport, 2nd ed. CRC Press, P. 185-213.

Kose, K., Dogan, P., Ozesmi, C. (1993). Contraceptive steroids increase erythroc-lipid peroxidation in female rats. Contraception, 47, 421-425.

Massafra, C., Gioia, D., De Felice, C. et al. (2000). Effects of estrogens and androgens on erythrocyte antioxidant superoxide dismutase, catalase and glutathione peroxidase activities during the menstrual cycle. Journal of Endocrinology, 167, 447-452.

Moller, S. E., Mach-Moller, B., Olesen, M., Fjalland, B. (1996). Effects of oral contraceptives on plasma neutral amino acids and cholesterol during a menstrual cycle. European Journal of Clinical Pharmacology, 50, 179184.

Norman, R. J., Clark, A. M. (1998). Obesity and reproductive disorders: A review. Reproduction, Fertility and Development, 10, 55-63.

De Souza, M. J., Maguire, M. S., Rubin, K. R. (1990). Effects of menstrual phase and amenorrhea on exercise performance in runners. Medicine \& Science in Sports \& Exercise, 22 (5), 575-580.

Stachenfeld, N. S., DiPietro, L., Kokoszka, C. A. (1999). Physiological variability of fluid-regulation hormones in young women. Journal of Applied Physiology, 86 (3), 1092-1096.

Stachenfeld, N. S. (2008). Sex hormone effects on body fluid regulation. Exercise Sport Science Review, 36 (3), 152-159.

Stachenfeld, N. S., Silva, C., Keefe, D. L. (2000). Estrogen modifies the temperature effects of progesterone. Journal of Applied Physiology, 88 (5), 1643-1649.

Sugioka, K., Shimosegawa, Y., Nakano, M. (1987). Estrogens as natural antioxidants of membrane phospholipid peroxidation. FEBS Letter, 210, 37-39.

Tiidus, P. M. (1995). Can estrogen diminish exercise induced muscle damage? Canadian Journal of Applied Physiology, 20, 1, 26-38.

Wabitsch, M., Hauner, H., Heinze, E. et al. (1995). Body fat distribution and steroid hormone concentrations in obese adolescent girls before and after weight reduction. Journal of Clinical Endocrinology \& Metabolism, 80, $3469-3475$.

Watson, P. E., Robinson, M. F. (1965). Variations in bodyweight of young women during the menstrual cycle. British Journal of Nutrition, 19, 237-248.

Ziomkiewicz, A., Ellison, P. T., Lipson, S. F., Thune, I., Jasienska, G. (2008). Body fat, energy balance and estradiol levels: A study based on hormonal profiles from complete menstrual cycles. Human Reproduction, 23, 11, 2555- 
2563

\title{
KREATINKINAZĖS, LIPIDŲ KONCENTRACIJOS IR KŪNO KOMPOZICIJOS PRIKLAUSOMUMAS NUO MENSTRUACINIO CIKLO FAZIŲ
}

\author{
Laura Daniusevičiūtè ${ }^{1,2}$, Marius Brazaitis ${ }^{1}$, Albertas Skurvydas ${ }^{1}$, Saulè Sipavičiene் ${ }^{1}$, \\ Vitas Linonis $^{2}$, Jurgita Piečaitiené ${ }^{1}$, Nerijus Eimantas ${ }^{1}$ \\ Lietuvos kūno kultūros akademija', Kaunas, Kauno technologijos universitetas ${ }^{2}$, Kaunas, Lietuva
}

\section{SANTRAUKA}

Tyrimo tikslas — nustatyti kreatinkinazès, lipidų koncentracijos, kūno kompozicijos priklausomumą nuo menstruacinio ciklo fazių: folikulinès ir ovuliacijos.

Tiriamosios - sveikos nesportuojančios, turinčios natūralų mėnesinių ciklą, fiziškai aktyvios merginos (n=9), kuriu amžius 19-23 m., kūno mase $58,2 \pm 6,1 \mathrm{~kg}$, ūgis 168,4 $\pm 5,6 \mathrm{~cm}$. Visos tiriamosios nevartojo hormoninių preparatų ne mažiau kaip 6 mènesius ir turèjo reguliarų menstruacini ciklą.

Kiekvieno eksperimento pradžioje buvo paimamas $5 \mathrm{ml}$ veninio kraujo mėginys menstruacinio ciklo fazèms (folikulinei ir ovuliacijos) nustatyti. Tyrimo metu estradiolio koncentracija kraujyje nustatyta antrą dieną nuo menstruacinio ciklo pradžios (folikulinèje fazèje) ir 14 dieną nuo menstruacinio ciklo pradžios (ovuliacijos metu). Eksperimentų dienas paskirdavo tyrèjas, atsižvelgdamas ị kiekvienos tiriamosios mènesiniu ciklo trukmę ir ovuliacijos dieną. Kiekviena tiriamoji 3 mènesius prieš eksperimentą matavo rektalinę temperatūrą - šitaip nustatyta mènesinių ciklo trukmé, reguliarumas. Kiekvieno eksperimento pradžioje buvo išmatuojami kūno kompozicijos rodikliai: kūno masė $(\mathrm{kg})$, kūno masės indeksas, riebalu kiekis (\%), riebalų mase $(\mathrm{kg})$, vandens kiekis (kg). Taip pat kiekvieno eksperimento pradžioje buvo paimamas $2 \mathrm{ml}$ veninio kraujo mėginys bendrojo cholesterolio, didelio tankio lipoproteinų cholesterolio, triacilgliceroliu ir kreatinkinazės koncentracijai kraujyje nustatyti. Kreatinkinazès koncentracija kraujyje buvo matuojama praejjus $24,48,72 \mathrm{~h}$ po krūvio (100 vertikalių šuolių nuo $75 \mathrm{~cm}$ kontakinès platformos). Tiriamosios po 10-15 min neintensyvios pramankštos (lèto važiavimo velorgometru, kai pulso dažnis $120-130 \mathrm{k}$. / min) ant kontaktinès platformos nuo $75 \mathrm{~cm}$ aukščio pakylos atliko 100 šuoliu, amortizuojamai pritūpdamos per kelių sąnarius iki $90^{\circ}$ kampo (rankos ant juosmens). Laiko intervalas tarp visų šuoliu — 20 sekundžių.

Pagal tiriamuju estrogenų koncentracijos kiekị kraujyje buvo nustatyta tiksli menstruacinio ciklo fazè, tačiau skirtumas tarp kūno kompozijos rodiklų, triacilglicerolių nebuvo statistiškai reikšmingas. Tarp didelio tankio lipoproteinu cholesterolio, bendrojo cholesterolio rodikliu ir menstruacinio ciklo fazių buvo nustatytas statistiškai patikimas skirtumas ovuliacijos metu. Dẻl per mažo tiriamuju skaičiaus nebuvo nustatytas statistiškai patikimas skirtumas tarp kreatinkinazès koncentracijos ir menstruacinio ciklo fazių, nors kreatinkinazės koncentracija buvo didesnè folikulinèje fazèje nei ovuliacijos metu.

Raktažodžiai: lipidų ir kreatinkinazės koncentracija, kūno kompozicija, folikulinè fazè, ovuliacija.

Gauta 2010 m. sausio 7 d.

Received on 7 January, 2010

Priimta 2010 m. gegužès 31 d.

Accepted on May 31, 2010
Laura Daniusevičiūtè

Lithuanian Academy of Physical Education

(Lietuvos kūno kultūros akademija)

Sporto str. 6, LT-44221 Kaunas

Lithuania (Lietuva)

Tel +37060065490

E-maillauruka@yahoo.com 